Migration Studies - Review of Polish Diaspora nr 3 (177)/2020, http://www.ejournals.eu/Studia-Migracyjne/ DOI: 10.4467/25444972SMPP.20.032.12596

\title{
Migrant female Musicians and their Fight for Social Rights ${ }^{1}$
}

\author{
MILENA GAMMAITONI² \\ ORCID: 0000-0002-6578-8199 \\ Department of Educational Sciences \\ Roma Tre University of Rome
}

The aim of this essay is to examine the social action of women composers, often obliged to migrate, for long or short periods, in search of greater freedom and affirmation of their musical talent. The history of yesterday and today features numerous women musicians, composers and performers, active in the production of music, in social and political life, who often had and have to travel and migrate to assert themselves. Going on tour has always been part of the life of the artist - but for women it was not easy to travel freely and at will, on their own besides. Until the nineteenth century, such a thing was almost always strictly forbidden. Sometimes women composers and performers left the countries in which they resided for personal reasons, driven not only by the "compulsion" to change country because in their own it was impossible to choose the pathway they wished to follow.

Keywords: women composers, sociology, rights, migration

\section{Social history of women composers and research methodology}

The Universal Encyclopedism of the eighteenth century and the various specialist disciplines cancelled women composers from the collective memory. As a result, they are often totally absent from present-day handbooks of the history of music. Today, it is possible to calculate their approximate numbers: the New Grove of Music lists 900 female musicians, the Oxford Library 1,500 and, finally, the "Donne e Musica"3

\footnotetext{
1 Translation from Italian by Kay Mc Carthy.

2 Contact: milena.gammaitoni@uniroma3.it

3 www.donneinmusica.org, and www.kapralova. org
} 
Foundation 27,000 women composers, interpreters, teachers and musicologists active in 108 countries and 84 associations $^{4}$. They are forgotten by the conservatories and histories of music, by formal and institutionalised seats and sources of knowledge $^{5}$, and even if mentioned on the web, in order to find them you need to know their names. Paradoxically, on the web the Italian word "compositrice" 6 is used to describe a typographic machine (sic!).

If the history of musicians and composers does not enter fully into the books used to teach the history of music in the Italian conservatories, this simply confirms the alleged "natural order of things" due to a prevailing historical construct which now sounds very much out of joint. To date, in Italy, as in other European countries, it is only thanks to the initiative of single teachers that some female composers have entered the syllabi and become the object of final exams at the conservatories ${ }^{7}$.

In 2003, a first data-collection campaign ${ }^{8}$ confirmed, unfortunately, the following state of affairs: the almost total absence of music by female composers from

${ }^{4}$ A woman who decides to become a composer, in Italy, cannot fail to take into account that she is entering a traditionally masculine field, which needs historical acknowledgement, hence the need to demonstrate that she is following an important though practically unknown pathway, that of historical female composition. The female performer-composer, therefore, is more deeply engaged in researching and disseminating much than her male colleagues. On the basis of culture and mentality, they rarely work as part of a team, but there are some exceptions. In 2001, eight composers from the Marche Region founded, in Recanati, "Donne in Musica" (women in music) with the support of the Adkins Chiti Foundation (the only foundation in Italy to promote female music), the "Artemusi(c) a-Compositrici per le Marche" association.

${ }^{5}$ The famous music historian Charles Rosen dismissed the existence of female musicians as follows, "No attempt is made (in this book n.d.r.) to resurrect those few female musicians whose production was almost completely inhibited during this period. I believe that doing so would distort the authentic tragedy that struck nineteenth-century female composers. It is misleading to emphasise the fact that there were some whose remarkable achievements were set aside and passed over in silence (...). These women composers were cruelly excluded from history and the attempt to reinstate them, uncritically and without discernment, does not do them posthumous justice or show how difficult their lives were". See C. Rosen (1997), La generazione romantica, Milano: Adelphi, p. 15.

"Unlike the Italian feminine substantive "compositrice", the English noun "composer" is common gender. To convey the meaning of the Italian "compositrice" the adjective "female" or the noun "woman" acting as an adjective, needs to precede the noun "composer" to render the meaning in English. Furthermore, in Italian the word-ending "-trice" can indicate both persons and things.

7 The Magistrae Musicae association, at the Conservatories of Novara, Milan, Bologna has launched a series of seminars, exhibitions and initiatives dedicated to students, in particular The artistic research project "L'ombra illuminata. Donne nella musica" - illuminated shadow. Women in music - under way at the Piccinni Conservatory in Bari, focuses on important and little-known works by historical female composers.

${ }^{8}$ An investigation into the concerts held by the most important musical artistic institutions and called "Gatekeepers", promoted by the European Community, coordinated by the German research institute ERICARTS, aimed principally at monitoring the actual effects of the 1998 Amsterdam Treaty on equal opportunities for women and men. In the case of Italy, the musical production of six orchestras and four festivals over the 1998-2002 five-year period was monitored. The music featured in these calendars were mainly by contemporary twentieth-century female composers: Ali-Zadeh Franghitz, Joanne Bailie, Sandra Bellino, Sonia Italia Bo, Paola Brino, Tomoko Fukui, Ada Gentile, Kostantina Gourzi, Eleni Karaindrou, Lisa Lim, Paola Livorsi, Nicoletta Malagotti, Laurie Mc Donald, Paola Minetti, Lara Morciano, Betty Olivero, 


\section{SM̂PP}

the concert programmes of Italy's major musical institutions, where, out of a total of 1,768 only 30 were compositions by Italian or foreign female composers, with the Italians accounting for a mere $0.3 \%$.

In 2015, to report and fill this institutional void, the Roma Tre State University established a Study Day to be held annually" and founded an editorial series, "Voci di Musiciste" 10 to provide an in-depth platform aimed at recovering and giving voice to the manuscripts of the many female composers of the past and present.

This attempt at popularising and teaching the subject has come up against the barrier of an audience of students who find it difficult, because they lack the necessary intellectual bases, to overcome a number of prejudices they entertain concerning the value of musical works, and their sceptic unwillingness to break with a tradition which excluded female musicians from the category of genius, therefore, from historical memory. Female musicians have been subjected to censorship as well as ghettoising and marginalising stereotypes, so much so that it has earned them the stigma of three-fold deviance: that of being women rebelling against the customs of their times, of exercising an art considered even today marginal compared to other artistic expressions ${ }^{11}$, and often of being migrant artists, therefore, traditionally deviant individuals, extravagant at best.

The research conducted here was, therefore, of an explanatory and exploratory nature and is presented as an investigation that has:

- followed the life stories and works of emblematic female musicians from different historical periods, chosen on the basis of uniform social characteristics;

- identified women artists, little-known in musical, literary, psychological and philosophical spheres, which constitute stages of transition in the social history of music;

- traced the life histories of these musicians, with the intention of carrying out an analysis that took mainly social, historical, anthropological, psychic factors into account, not exclusively aesthetic ones;

Schiphorst, Roberta Vacca, Aleksandra Vebralov, Julia Wolfe. See: S. Piras La ricerca per la Comunità Europea: la non pari opportunità nella programmazione musicale italian and Adkins Chiti Foundation (2003), Una visione diversa, la creatività femminile in Italia tra l'anno Mille e il 1700, Milano: Mondadori Electa.

9 The Study Day conceived by Milena Gammaitoni is now at its third edition - in collaboration with Luca Aversano (DAMS Università Roma Tre), Orietta Caianiello (Conservatory of Bari), Gilberto Scaramuzzo (Roma Tre University) - held every year by the University of Roma Tre, Department of Education and the Palladium Theatre Foundation. Each year, the Study Day hosts reports by teachers from the Conservatories professors, musicologists, historians, sociologists and educationalists and brings together the testimonials of contemporary composers and offers interludes featuring artistic and musical performances.

In the premises of the Department of Education, a photographic, documentary exhibition has been set up dedicated to female composers from different countries all over the world, organised by the Female Toponymy Association.

10 The "Voci di Musiciste" series by SEdM Edizioni, is edited by Luca Aversano, Orietta Caianiello and Milena Gammaitoni.

11 In Italy, music remains a marginal subject in the curriculum of state schools, and is, therefore, still an elitist practice, see www.miur.it 
- analysed the life-stories of the best-known female musicians with a view to debunking prejudices and stigmas concerning them;

- identified the types of musicians to be examined according to the historical and social significance of the changes their lives underwent due to migration;

- selected a significant sample of female musicians on the basis of their originality, status and social roles;

- analysed historiographical data of each of them within their various artistic fields, drawing from official and non-official sources, like employment contracts, commissions, chronicles, biographies, letters, in order to understand, by following the evolution of experience, the "daily" aspect of the lives of female musicians, with a view to grasping the reasons why they did not make history.

- interpreted, on the basis of qualitative analysis, the synergy existing between the work and the social identity of each musician, so as to provide a diachronic social analysis starting from single stories which define a kind of social action where private and public spaces crossed.

Yet, it is surprising to discover that in actual fact the majority of them were born into families of artists enjoying socially elitist conditions, leading a fairly traditional private life as a norm. Furthermore, while marrying, they also studied and created musical works, became mothers, opened schools, taught in conservatories, performed their own works.

Until the middle of the 19th century they studied professionally thanks to their families. All the women belonging to the elite played a musical instrument, usually the piano, as amateurs with a view to enhancing their so-called female accomplishments. It was only after 1870 that the conservatives began to admit them to classes of orchestral rehearsal and composition. These included the Venetian musical Hospitals and the Conservatories of Germany, France and England. The Paris Conservatory, founded in 1795, and the Royal Academy of Music in London, opened in 1823, accepted both men and women, but, all over Europe women were allowed to attend on days and at times different from men and follow more modest syllabi - "especially gauged to their requirements" - which the study of many instruments was forbidden (the 'cello, wind instruments, etc.) due to the unseemly physical position they required, considered unsuited to female dignity and a woman's reputation ${ }^{12}$.

Undoubtedly, the proliferation of Conservatories provided more room for women, as in the case of Maria Pleyel and Pauline Viardot, and Louise Farrenc who taught at the Paris Conservatory for thirty years. Their status as teachers permitted them to make their works known, both for didactic purposes and in concerts. This was the

12 Cfr. P. Adkins Chiti (1991), Almanacco delle virtuose primedonne, compositrici e musiciste d'Italia, Novara: Istituto Geografico De Agostini; G. Bock (2001), Le donne nella storia europea, Roma: Laterza; M. Mead, Maschio e femmina (1972), Milano: II Saggiatore; A. Trasforini (2000), Arte a parte. Donne artiste fra margini e centro, Milano: Franco Angeli; M. Zucca (2010), Storia delle donne, da Eva a domani, 
case first of the famous Polish female composer, Maria Szymanowska, later of Clara Wieck Schumann, Louise Adolphe Le Beau and Agathe Backer Grondal.

In each country, we can trace the different histories and institutional pathways these women pursued. At the end of the 1800s the director of the Milan Conservatory, Antonio Bazzini, publicly shared concerns regarding the "question of womern enrolled in composition classes", declaring that the only candidate worthy of admission to the class that year had been a woman: Antonietta Gàmbara Untersteiner ${ }^{13}$.

The female composers permitted to study, even if they did not belong to the aristocracy, were, in particular, the French and the English. In Germany, Austria, Italy and Spain women musicians belonged to an elite and, for the most part, attended schools closely related to the royal courts or aristocratic life, where they could study and become professionals, though they were allowed very little freedom to disseminate and circulate their works.

None of them were allowed to enter national orchestras or operatic companies, which is why some of them decided to organise female ensembles and orchestras independently. When, at the end of the 19th century, the middle class began its ascent, and schools became accessible to different social strata, new female composers from different backgrounds managed to emerge like Augusta Holmès (1847-1903), Cecile Chaminade (1857-1944), Ethel Smyth (1858-1944).

Nowadays, historiographical research combined with sociological interpretation makes it increasingly clear that, albeit in a discontinuous and elitist fashion ${ }^{14}$, female musicians were sometimes able to enjoy privileged status, especially within the courts, where, if born into families of musicians, they worked and were often well paid so they might bring prestige to their micro-society of reference and to the different rivalling European courts. These spaces of public acclaim came to an end, paradoxically, with the democratisation of knowledge - the enlightenment and encyclopedism of the eighteenth century, the institutionalisation of the various disciplines and mass education which began at the end of the nineteenth century - which prevented women from acceding to higher education, to avoid autonomous, that creative, genial women artists might become an aspect of a consolidated, generalised practice ${ }^{15}$. Consolidated tradition did not acknowledge them, until the feminist movements of the twentieth century made it clear that women could enjoy civil and political liberties and, therefore,

${ }^{13}$ From the exchange of letters with the director of the San Pietro a Majella, Giuseppe Martucci, Archivio Donne in Musica, Fiuggi.

${ }^{14}$ Normally only women of the nobility or the daughters of artists could study music in a professional, non-amatorial way. In Europe it was only after the revolutionary movements of the 1800s and 1900s that artists from the bourgeoisie or the middling-bourgeoisie emerged exceptionally.

${ }^{15}$ When at the end of the nineteenth century the cities of Northern Europe allowed women to enter the Conservatory to study, they could do so only on days and times different from those of men, and followed reduced syllabi "pour les jeunes filles" and when they managed to become teachers at the conservatory they could only teach to female classes, Cfr. K. Pendle (1991), Women and Music: a History, Indiana University Press. 
the right to study at higher level and make their mark upon ambits considered the reserves of males only. Female artists, many of them musicians, managed to create their own works regardless, but having their works performed in theatre, publishing them and divulging them has often been difficult, at times impossible.

Today, the prodigious work of recovery of historical manuscripts (autobiographies, letters, biographies, memoirs) and of the musical transcriptions of female composers' works, has made the diffusion and publication of their music, possible, especially on the web, but often it is necessary to know their names to access them.

The life of these women artists has been and remains even today what Marcel Mauss would call "a total social fact"16, because the synergy between the work and social identity of each artist provides the opportunity of carrying out diachronic analyses starting from the individual stories which define a kind of social action where the private and public domains meet. Music permeates the daily life of every musician, where work time and non-work time are not clearly separated (with fixed hours, summer breaks, etc.); creation is often carried out in different places (the home, an institution ) and at various times (morning, afternoon, evening, night) undefined in a structured way ${ }^{17}$. Women musicians fought to obtain the freedom to study, work, and have their compositions performed in public; they have followed formal and informal pathways, in a context of family's daily life, in micro social reference systems (courts, salons, clubs, etc.), up until the era of popular revolution.

In the remote past, it was possible to find the female musicians who denounced the injustices the underwent in their private and social lives: the Trobairitz, who often travelled, were foreigners in the various European courts. In the Middle Ages the troubadours were not only men: even some women of the lower classes became court musicians and used the art of verse not to idealise love, but to denounce abuse, betrayal and the unhappiness of everyday life. For example, Beatriz, Countess de Dia who lived during the second half of the 12th century, was the most prestigious female voice of the troubadour school. She lived between Provence and Lombardy. In her proud, elegant lines, she used language considered unprejudiced back then:

\footnotetext{
"I have to sing what I would prefer not to, he whose beloved I am embitters me, because I love him more than anything else; with him grace and courtesy benefit me none, nor do my beauty, merit or intellect, because I am deceived, betrayed, how just that would be were I guilty"18.
}

${ }^{16}$ Cfr., M. Mauss (2018), Manuale di etnografia, Milano: Jaca Book.

17 V. Zolberg, Sociologia dell'arte (1994), Bologna: II Mulino.

18 "Devo cantare ciò che non vorrei, tanto mi amareggia colui di cui sono l'amore, poiché l'amo più di ogni altra cosa; 


\section{SM̂PP}

The legacy of the Trobairitz reached the twentieth century with the great women jazz musicians and blues singers and the most recent revolutionary troubadours singing in defence of oppressed peoples, like Violeta Parra, Mercedes Sosa, who had to leave her country for reasons of politics and censorship, the anti-war rock of the 1970s, the Italian folk-popular music ${ }^{19}$ and rap denouncing the social marginalisation of youth subculture.

In the 1700s, there were important women composers and conductors who achieved fame and occupied professional spaces ${ }^{20}$, but it was necessary to await the end of the 19th century to find traces of female musicians who entered the arena of public speech and the fight for political and civil rights. Elfrida Andrée, Agathe Ursula Backer Grondahl, Louisa Adolpha Le Beau, Ethel Mary Smyth, Philippine Schick, Emilia Gubitosi, Maria Cusenza, Giulia Recli, were the female composers, who more than others, emerged between the end of the 19th century and the first half of the 20th, and were committed to the recognition of social rights. Even before political rights they claimed the concrete, not simply theoretical, possibility, of freely occupying institutional roles ${ }^{21}$ : chairs at the Conservatories, in the schools of music, posts as directors of musical associations. Some of them even established female orchestras like the "Vienna Ladies Orchestra" (1867), conducted by Josephine Weinlich, who was able to work only by changing her place of residence, from Vienna to Lisbon; or the "Fadette Women's Orchestra" (1868), conducted by Caroline Nichols, or the "Philadelphia Symphony Orchestra" (1921), conducted by F. Lehman.

Even today, while the West has to coexist with die-hard stereotypes, in the Middle East some female musicians emerge rebelling against religious and political domination: exemplary is the story of Negin Khpolwak, the first conductor we know about thanks to the mass media and social networks. Negin does not wear a veil, she is twenty years old and rebels against the Talibans who prevented her from studying music, so much so, that during one of her concerts a suicide bomber blew himself

con lui grazia e cortesia non mi giovano,

né la mia bellezza, merito o intelletto,

perché sono ingannata, tradita

quanto sarebbe giusto se fossi colpevole"

In "Le manuscript du roi", a songbook dating 1270 copied for Charles of Anjou.

19 Many female musicians of the twentieth-century Italian folk tradition performed this kind of everyday music to denounce the fatigue and injustices of farm and factory work, female subordination and violence in the family. In particular, Rosa Balistrieri and Caterina Bueno need to be mentioned in this sense. Elisabeth Jacquet de la Guerre, composer at the court of Louis IV, Sun King, conducted ballets and cantatas. In the 18th century Marianna Martinez, a friend of Mozart's, conducted masses and oratories in Vienna, in the nineteenth century Fanny Mendelssohn conducted works by Gluck, Mozart and Beethoven (n.d.a.).

${ }^{20}$ For example, Elisabeth Jacquet de la Guerre, composer at the court of Louis IV, the Sun King, conducted ballets and cantatas; in the 18th century Marianna Martinez, a friend of Mozart's, directed masses and oratories in Vienna, in the nineteenth century Fanny Mendelssohn conducted works by Gluck, Mozart, and Beethoven (n.d.a.). 
up in the audience. Unfortunately, she declares, the whole family, with the exception of her father, has repudiated her:

“For my people I am a disgrace. Because I go to school. Because I make music. (...) Many would like to shut us up inside the home, stop us from making music. I want to prove every day that Afghan women can do everything. I care, I won't stop. I owe it to other women"22.

She is currently touring Europe with her orchestra.

Another exemplary story of denunciation is that of Sonità, an Afghan rapper fighting against Sharia. Her family chose to marry her off at the age of fourteen to a man willing to pay nine thousand dollars for her. With that money Sonità's brother was able to buy a wife.

He song cries out in protest:

"Allow me to whisper these words to you, so that nobody may hear that I'm telling about the girls who are sold. My voice should not be heard because it goes against the Sharia, women must remain silent" ${ }^{\prime 23}$.

At the age of ten, Sonità fled to Iran, far away from the Taliban regime, but she could not attend school because she was a refugee and had no documents, so Sonità started attending an NGO where she also studied music, with a preference for hip-hop. In Tehran she began telling her story in song. She composed a hymn to peace and a piece in favour of democratic elections in Afghanistan, overcoming the prohibition forbidding women to make music in Iran.

Perhaps, as Herbert Marcuse wrote, true utopian and revolutionary action will take place thanks to the rebelling populations of countries said to belong to the "Third World" because:

"They remain outside of the democratic process; their presence proves, as never before, how immediate and real is the need to put an end to intolerable conditions and institutions" 24 .

The female Moroccan sociologist and writer, Fatima Mernissi, in the 1980s had already foreseen that the use of the internet would have become an instrument of emancipation and of greater openness and freedom for women and for peoples subjected to censorship, prevented, therefore from even the thought of getting in touch with other worlds:

22 From an interview conducted by Tonia Mastrobuoni, http://www.repubblica.it/esteri/2017/01/19/ news/negid khpolwak_afgana-156407414/?refresh_ce

${ }^{23}$ From the Rap composition "Bride for sale". The story of Sonita is presented in the documentary 


\section{SM̂PP}

"Education means getting to know the hududs, the sacred borders" said Lalla Tam, female director of the Koranic school where, at the age of three, she was sent to join her ten cousins, "I passionately wanted to please Lalla Tam, and once she was not within earshot I asked my cousin Malika, two years older than me, if she would show me the exact point where the hududs were. Since then, seeking borders has become the occupation of my life". ${ }^{25}$

In the history of female musicians and their visibility, the use of the internet provides easy access and disclosure, provided however that we know their names. International associations are active within the web, but their concrete presence in the musical programmes of the major European musical institutions is still scarce.

Today, the struggle for recognition of their social rights conducted by female musicians all over the world and by those who study and support them, no longer regards access to courses of higher education or teaching posts in the conservatories, but the propagation and performance of the hundreds of works women have created from antiquity to the present, as well as access to the artistic direction of civic theatres and state orchestra.

\section{Conclusions}

The cultural legacy of the historiographic silence regarding women as active subjects of history continues to risk neutralising difference through monological discourse, which imposes stereotypes upon the socialisation of the new generations. Often considered marginal compared to the other arts, music seems to share the fate of women, also left on the fringes of history ${ }^{26}$.

"Women are first described, then narrated, long before they speak. Only their literary images seem to enjoy greater depth at times; voted over the centuries to the silence of reproduction, the shades of history, they experience art in the intimacy of convents, in the subjection of their homes, a kind of art not worth handing down"27.

The life of these composers was and still is what Marcel Mauss would call "a total social fact" 28 , because the synergy between the work and the social identity of each artist offers the opportunity for a diachronic analysis starting from single stories that define a social act in which private and public spaces come together. Art permeates the daily life of each artist, where the working time and the non-working time are not clearly separated (with fixed times, summer breaks, etc.), often the creation takes place in places (one's home, in institutions) and times (morning, afternoon, evening,

25 Cfr. F. Mernissi (1996), La terrazza proibita. Vita nell'harem, Firenze: Giunti, p. 42.

26 Cfr. E. Fubini (1995), Estetica della musica, Bologna: Il Mulino.

27 G. Duby, M. Perrot (1990), Storia delle donne, L'Antichità, Rome-Bari: Laterza, p. V.

28 M. Mauss, Manuale di etnografia, op. cit., p. 92. 
night) not defined in a structured way. In the history of humanity, the artists have struggled to obtain freedom to study, work, and visibility of their creations; they have followed formal and informal paths, within the daily life of their family, in the micro social systems of reference, and this is even more true for foreign artists and immigrants from their country of origin.

The big news, writes Catherine Withol de Wenden, is that "today migration is considered as a factor of development. After studies on the subject have oscillated between the plunder of the Third World, unequal exchange and development as an alternative to migration, today all the works agree in recognizing that migration and development go hand in hand: transfers of remittances are linked the modernization of the starting societies from an economic, but also cultural and political point of view"29.

Yet behavioural models and values are transmitted through women. As nurses, nursemaids, governesses, mothers, teachers, they play the most significant role in the socialisation of children.

It is significant that Santa Cecilia, patroness of music, symbol of one of the world's prestigious conservatories ${ }^{30}$, was not actually a musician. Cecilia was a patrician who wanted to dedicate herself to virginity, so much so that she persuaded her husband to become a Christian, the reason why both of them were sentenced to death. Cecilia was canonised later and portrayed with a musical instrument in her arms.

Women musicians have often been subject to censorship, prejudices and ghettoizing and marginalizing stereotypes, so as to stigmatize them in a double deviance: that of being rebellious women against the customs of their time and culture, of exercising a creative activity still considered marginal today compared to the world economic entrepreneurship or freelance, that of being artists and therefore traditionally deviant individuals, or extravagant in the best case. To these two stereotypes, one often adds what defines migrants and migrants who bring poverty and hardships, forgetting how essential their work is to the European economy and welfare.

Most of the manuscripts and many of the first issues of the music written by women 1500s and 1600s were and remain anonymous. It was only at the end of 1600 s that they began to sign their works.

In the seventeenth century, Francesca Caccini was able to stage "La Liberazione di Ruggero dall'Isola di Alcina"31, the first Italian opera ever performed in Poland. She worked - one of the highest paid there - at the court of the Medici family in Florence, travelled throughout Europe and had her work performed in Warsaw. In eighteenth-century Rome, Maria Rosa Coccia began composing at the age of fifteen and was appointed Kapellmeister, a profession until then reserved to men alone. In 1882, Emil Naumann wrote in The History of Music: "We know that all creative work is the prerogative of men".

${ }^{29}$ Cfr. C. Withol de Wenden, /l diritto di migrare (2015), Roma: Ediesse, p.56.

30 Rome's Conservatorio di Santa Cecilia.

${ }^{31}$ La liberazione di Ruggiero dall'isola d'Alcina, (1625). 


\section{SM̂PP}

Among the traditional occupational models for women is teaching, a purely feminine role; in the musical field a teaching post at a conservatory represents a point of arrival for many female musicians ${ }^{32}$. In the latest Italian census, among the highprofile intellectual professions that of the artist has appeared at last. The aggregate category of composers, musicians and singers numbered 19,000 of whom only $18 \%$ women, however ${ }^{33}$.

Another purely feminine role is the opera singer. This because she is not generally considered a true musician because of the brevity of the practical and theoretical educational course required for that instrument, her voice, intended exclusively for opera. The female opera singer is often considered a race apart, a coquette, a prima donna, "a virago, a grand dame, difficult, nervous, lazy, greedy, jealous, self-centred and a spendthrift". ${ }^{34}$

The iron law of the oligarchy described by Robert Michels might be reworded here on the basis of the dynamics of a self-justified historical circle whereby habit becomes acquired behaviour. The needs of an organised minority - Michels wrote create a tendency towards oligarchy, "a minority which has the task of directing and a majority directed by the former. Technical specialisation, a necessary consequence of every complex organisation, creates the need for so-called competence-based management, so that all the decision-making powers of the masses regarding technical matters, are transferred to managers only". 35

As Ralph Darendhorf ${ }^{36}$ posited, before a norm can become customary, decades may pass, because citizens do not easily and promptly internalise rights sanctioned by rules considered extraneous to their cultural habits. This is how we may explain the institutionalised marginality of many of the female composers operating within the creative and social sphere; the difficulties associated with the possibility of being admitted to schools and courses reserved for men, of being able to perform in public and sign their own works.

Even today, the collective imagination pictures the conductor, the composer, the luthier as male professions. The conductor, Elke Mascha Blankenburg ${ }^{37}$, in her book on the world's female conductors ${ }^{38}$, brings to light existential pathways with

32 A. Trasforrini (2000), Arte a parte. Donne artiste fra margini e centro, Milano: Franco Angeli.

33 Dati Istat 2014/2016. Mentre, nei corsi AFAM nel 2016 sono stati censiti 4.818 studenti iscritti, di cui 2.047 donne e 544 stranieri. Personale docente 6.319 (dati Miur).

${ }^{34}$ P. Adkins Chiti (1991), Almanacco delle virtuose primedonne, compositrici e musiciste d'Italia, Novara: Istituto Geografico De Agostini, p. 23.

35 R. Michels (1966), Sociologia del partito politico, (1911), Bologna: II Mulino, p.70.

${ }^{36}$ R. Darendhorf (1966), Homo sociologicus: uno studio sulla storia, il significato e la critica della categoria di ruolo sociale, Bari: Laterza.

${ }^{37}$ E.M. Blankenburg, was one of Europe's first female orchestral conductors in a purely male environment. She took active part in the feminist movements of the 1960s and 1970s and founded the Clara Wieck Schumann Association in Cologne, still engaged in the study and promotion of the female composers.

${ }^{38}$ E.M. Blankenburg (2003), Direttrici d'orchestra nel Ventesimo Secolo, Hamburg: Europaeische Verlagsanstalt. 
similar characteristics: the great psychological and physical burden of trying to work in an exclusively male and highly discriminatory environment; a private life that is more difficult and often full of misunderstandings with one's partner. Then comes renouncement of one's career, around the age of fifty, which, according to the author, is due to social prejudice whereby a young woman who attracts curiosity is worth exhibiting, while an older woman on the podium is not socially desirable, so that none of them has never received proposals to conduct once they have passed the threshold of middle age.

This provides the measure of the enormous effort in education and dissemination that needs to be undertaken to involve the new generations, starting from the language: the image transmitted by popular literary texts (in Italy for example those most frequently studied at school are Alessandro Manzoni's I Promessi Sposi, Natalia Ginsburg's Lessico famigliare, Giovanni Verga's I Malavoglia, Dante Alighieri's Divine Comedy) is that of women playing traditional roles. They say nothing about the production of all those women who experienced art, politics, their economic independence with determination, strength and rebellion.

In the 21 st century, school texts continue to provide a history of women and their deeds which fails to look beyond the domestic environment, contributing to a contradictory socialisation of the sexes (according to Margareth Mead ${ }^{39}$ ). The difficulty, when internalising and defining roles, of recovering the historical reality denied means pursuing a new kind of socialisation not only of women but also of men.

"We know that all creative work is the exclusive prerogative of men" recites a manual of the history of music written in $1882^{40}$. A woman cannot be creative, nature itself prevents it, her biological inferiority does not permit her an independent existence; the future does not open up to the expression of her abilities, an attempt to achieve ambitions. "The Christian woman", writes Girolamo, "will be a virgin and virtuous, shall not read Cicero, Horace, Vergil, shall not write poems in lyric metre, she shall be deaf to song, to the zither, to the lyre, she shall study the sacred scriptures, she shall be content with melancholic handmaids, of a singing voice with which to chant sacred hymns day and night. She shall rely on the moral of a Latin epigraph: Casta fuit, domum servavit, lanam fecit" - she was chaste, looked after the house and spun wool.

Already in the Middle Ages the Benedictine nun Hildegard von Bingen was an excellent example not only of artistic creativity, but of the fight for freedom of action both inside and outside the walls of the monastery. Today, the struggle for recognition of their social rights conducted by female musicians and those who study and support them, no longer regards access to courses of higher education or teaching posts in the conservatories, but the dissemination and performance of the hundreds

39 M. Mead (1972), Maschio e femmina, Milano: Il Saggiatore.

40 P. Adkins Chiti, op. cit., p. 42. 


\section{SM̂PP}

of works women have created from antiquity to the present, as well as access to the artistic direction of civic theatres and state orchestras.

In the case of the history of the composers and their visibility, surely the use of the internet has allowed an easy availability and the immediacy of their disclosure, provided that their names are known.

Furthermore, the independence of the artist is linked to the value of what he/she creates and this value is determined when art becomes a commodity of commercial exchange. Its value, or rather the value of the artist, is, thus, translated into money.

The difficulty of considering artists as entrepreneurs depends on two attitudes: on the one hand, the social imagination is still strongly grounded in the history of patronage, on the other, even today the effects of directly and indirectly induced activities, cause underestimation of the impact of artistic creation on the public and the influence it exerts over so-called consumer choices regarding tangible and intangible goods. The history of the arts strongly has strongly corroborated the idea that artists do not entertain primarily economic-utilitarian aims, and that, therefore, their work, despite having economic repercussions, is considered too often marginal, something extra, if not useless.

Today, who are the artists that feature within the world of migrant entrepreneurship? They work in the crafts (seamstresses, leather-goods workers) in the creative sector (publishers, stylists, designers) and in the realm of what is canonically considered "art" (musicians, painters, dancers). They are barely acknowledged, because, often, if not famous and / or on some kind of contract, their source livelihood depends on other categories, which oscillate between home making, unemployment, trade, dependent employment.

In 2018, the total figure for foreign women registered as business owners in Italy stood at 8,391 , that is $1 \%{ }^{41}$ of the total, and clearly explains how difficult it is to bring together under a single aggregate heading an extremely heterogeneous set of professions: artists, sportsmen, and entrepreneurs dedicated to entertainment, amusement and leisure. It would be interesting to have the data for each category and try to understand the philosophy which leads many artists to register under the sports category.

Very often they are very particular immigrants, welcomed in Europe because of their high educational level and their fields of specialization. In everyday language and, to some extent, also in legal terms, male and female immigrants alike are those foreigners who live and work permanently in a country, but as French and German citizens. The Japanese are an exception as are the citizens of the USA though from a legal point of view, they too are technically immigrants. Yet, as Maurizio Ambrosini42 points out, very rarely is a US or Japanese citizen denied the right to enter, leave and circulate in our country, as well as bring his/her family. Even recognition of their

${ }^{41}$ IDOS, Istituto Demografico Ricerche sulla Popolazione.

42 M. Ambrosini (2017), Migrazioni, Milano: Pixel. 
qualifications receives preferential treatment compared to those of citizens from less powerful countries.

The phenomenon is complex and heterogeneous. Many artists, artisans and creative people come from countries whose citizens have not got the right to migrate and who, arrive in Europe as undocumented immigrants, surviving thanks to undeclared employment and the unable to obtain residence permits. By way of comparison, a European citizen can travel freely to and in 162 countries without visa, an Afghan can do likewise in only 30. Many other countries such as Somalia, Cuba, the Congo, India and others issue travel visas with extreme difficulty. In the case of many Bangladeshi and Chinese seamstresses, we find that they registered under the names of husbands or brothers. Hence, it is extremely difficult to trace and examine the entrepreneurial lives of many creative migrants, as well as those belonging to other sectors of entrepreneurship.

\section{References}

Adkins Chiti P. (1991), Almanacco delle virtuose primedonne, compositrici e musiciste d'Italia, Novara: Istituto Geografico De Agostini.

Adkins Chiti Foundation (2003), Una visione diversa, la creatività femminile in Italia tra I'anno Mille e il 1700, Milano: Mondadori Electa.

Ambrosini M. (2017), Migrazioni, Milano: Pixel.

Basso A. (1985), Dizionario Enciclopedico Universale della Musica e dei Musicisti, Le Biografie, Torino: UTET.

Blankenburg E.M. (2003), Direttrici d'orchestra nel Ventesimo Secolo, Hamburg: Europaeische Verlagsanstalt.

Bock G. (2001), Le donne nella storia europea, Roma: Laterza.

Bonaventura A. (1933), Almanacco della donna italiana, Firenze: Bemporad.

Cusick G.S. (2009), Francesca Caccini at the Medici Court: Music and the Circulation of Power, Chicago: University of Chicago Press.

Darendhorf R. (1996), Homo sociologicus: uno studio sulla storia, il significato e la critica della categoria di ruolo sociale, Bari: Laterza.

Duby G., Perrot M. (1990), Storia delle donne, Roma - Bari: Laterza.

Elsa E. (1975), L'Arte cambia sesso, Catania: Tringale.

Gammaitoni M. (2013), Storie di vita di artiste europee, dal Medioevo alla contemporaneità, Padova: Cleup.

Heinich N. (2005), La sociologia dell'arte, Bologna: II Mulino.

Marcuse H. (1968), L'uomo a una dimensione, Torino: Einaudi.

Mauss M. (2018), Manuale di etnografia, Milano: Jaca Book.

Mead M. (1972), Maschio e femmina, Milano: II Saggiatore.

Mernissi F. (1996), La terrazza proibita. Vita nell'harem, Firenze: Giunti.

Michels R. (1966), Sociologia del partito politico, (1911), Bologna: II Mulino.

The New Grove Dictionary of Music and Musicians (1980), ed. by Stanley Sadie, London: Mac Millan Publishers. 
Pendle K. (1991), Women and Music: A History, Bloomington: Indiana University Press.

Rosen C. (1997), La generazione romantica, Milano: Adelphi.

Trasforini A. (2000), Arte a parte. Donne artiste fra margini e centro, Milano: Franco Angeli. Withol de Wenden C. (2015), I/ diritto di migrare, Roma: Ediesse.

Wolff J. (1983), Sociologia delle arti, Bologna: II Mulino.

Zolberg V. (1994), Sociologia dell'arte, Bologna: II Mulino.

Zucca M. (2010), Storia delle donne, da Eva a domani, Napoli: Edizioni Simone. 